\title{
Academisation of the Midwifery Profession and the Implementation of Higher Education in the Context of the New Requirements for Licensure
}

\section{Akademisierung des Hebammenberufs und die Implementierung von Studiengängen im Kontext der neuen Anforderungen}

\section{(ㄷ) (1) (우)}

Authors

Joachim Graf ${ }^{1}$, Elisabeth Simoes ${ }^{2,3}$, Sina Blaschke ${ }^{1}$, Claudia F. Plappert ${ }^{1}$, Janice Hill ${ }^{1}$, Marie-Jeannine Riefert ${ }^{1,4}$, Harald Abele ${ }^{1,2}$

\section{Affiliations}

1 Universitätsklinikum Tübingen, Institut für Gesundheitswissenschaften, Abteilung für Hebammenwissenschaft, Tübingen, Germany

2 Universitätsklinikum Tübingen, Department für Frauengesundheit, Tübingen, Germany

3 Universitätsklinikum Tübingen, Stabsstelle Sozialmedizin, Tübingen, Germany

4 Universität Tübingen, Medizinische Fakultät, Dekanat Bereich Studium und Lehre, Tübingen, Germany

Key words

midwifery, academization, study course, challenges

Schlüsselwörter

Hebammenwissenschaft, Akademisierung, Studiengang, Herausforderungen

received $\quad 11.7 .2020$

accepted $\quad 31.7 .2020$

Bibliography

Geburtsh Frauenheilk 2020; 80: 1008-1015

DOI 10.1055/a-1138-1948

ISSN 0016-5751

(c) 2020. The Author(s). This is an open access article published by Thieme under the terms of the Creative Commons Attribution-NonDerivative-NonCommercial-License, permitting copying and reproduction so long as the original work is given appropriate credit. Contents may not be used for commercial purposes, or adapted, remixed, transformed or built upon. (https://creativecommons.org/licenses/by-nc-nd/4.0/)

\section{Correspondence}

Joachim Graf, M. A., M. Sc. Universitätsklinikum Tübingen, Institut für Gesundheitswissenschaften, Abteilung Hebammenwissenschaft Hoppe-Seyler-Straße 9, 72076 Tübingen, Germany

joachim.graf@med.uni-tuebingen.de

$\Theta$ Deutsche Version unter: https://doi.org/10.1055/a-1138-1948

\section{ABSTRACT}

The academization of the midwifery profession poses great challenges for Germany, especially due to the tight timelines: Corresponding courses of study can in principle be offered at both universities and technical colleges - although contrary to the recommendations of the Science Council. This means that there is a heterogeneity in midwifery qualifications and promotes a discussion regarding coherent study concepts. This process must be accompanied with great care so that midwifery courses of study are not designed to be of poorer quality than other courses of study due to a lack of financial resources. First concepts are already available and will be discussed and examined below.

\section{ZUSAMMENFASSUNG}

Die Akademisierung des Hebammenberufs stellt Deutschland vor allem durch die engen Zeitlinien vor große Herausforderungen: Entsprechende Studiengänge können grundsätzlich - wenngleich entgegen den Empfehlungen des Wissenschaftsrates - an allen Hochschulen stattfinden. Dies bedeutet eine Heterogenität in der Hebammenqualifizierung und fördert eine Diskussion bezüglich schlüssiger Studienkonzepte. Mit großem Bedacht muss dieser Prozess begleitet werden, damit Hebammenstudiengänge nicht unter dem Diktat mangelnder finanzieller Ressourcen qualitativ schlechter als 
andere Studiengänge ausgestaltet werden. Erste Konzepte liegen bereits vor und sollen im Folgenden diskutiert und beleuchtet werden.

\section{Background: Academisation and the Status Quo}

With the adoption of the new Midwifery Act (Hebammengesetz HebG), which came into force in January 2020, Germany has integrated midwifery training with higher education: In accordance with the requirements of the EU Directive 2005/36/EC, a 12-year general school education has been established as an essential criterion to begin training [1]. Furthermore, analogous to the other EU member states, a complete transfer of the midwifery qualification to higher education institutions was decided [2]. The law specifies that by 2023 midwifery training should be raised from the level of an apprenticeship occupation to an academic level, and that the training previously provided by vocational schools must also be replaced by academic training. This means that previous components of training must be reconsidered and redefined. In the future, students should receive their professional licensure together with their Bachelor's degree after completing a dual study course that provides primary qualifications [2]. The law stipulates that in the future theoretical teaching will be carried out at higher education institutions and practical teaching at cooperation hospitals. The teaching should be completely modular and convey evidence-based competencies. The number of practical hours has been reduced from 3000 to 2200, while at the same time the number of practical hours with structured practical instruction has been increased to $25 \%$. Furthermore, it was determined that students should receive remuneration for their practical work from the dual practice partner, for which purpose the Hospital Financing Act was also amended when the law was passed - a novelty with regard to primary qualification study courses with a health connection [2,3]. Against the background that currently two- thirds of all training places at nearly 60 midwifery schools are still placed at vocational schools and that the existing study courses are dominated by integrated training models (in cooperation with midwifery schools), which also lose their basis under the new law, the defined time horizon of three years for implementation appears very short [4]. The faculties are faced with the challenge of promptly creating curricula and examination formats for curricular teaching and practical training. It is the responsibility of the federal states to provide the necessary resources and define quality standards [5]. In this context, the aim of this publication is to outline the challenges associated with the change in legislation and to derive possible approaches to solving them.

\section{Challenges of the New Law}

The law poses a variety of challenges that influence the requisite full academization at various levels. One hurdle arises from an economic perspective: While vocational training at technical colleges was financed entirely through the health insurance funds, higher education will in the future have to be financed both by the federal states and the health insurance funds. As with other study courses, the financing of curricular training must be borne by the states. However, the amount of funding required is unclear, partly because the midwifery law was passed at the time of its adoption and the amount of work required of the states was calculated at far too low a level [6].

Internal calculations of the study programme in Tübingen estimate the total annual cost for curricular teaching for one place of study is at 25000 to 30000 Euros (depending on the size of the cohort), resulting in annual costs (excluding infrastructure and implementation costs) of almost 10 million euros for the state Baden-Württemberg alone, assuming full academization. The cost of study places in the field of midwifery science are not higher than the costs for study places in other bachelor degree courses. Due, however, to limited time horizons, the costs have not been taken into account in state budgets so far and therefore have to be woven into supplementary budgets. It is impermissable that a reduction in costs should impair the desired quality of the academic training, which stands up to comparison with other courses of study - not least in view of the fact that academically trained midwives are qualified to work independently in obstetrics after completing their 6-7 semester course of study.

In order to avoid underfunding the courses of study, locations that offer an academic qualification in midwifery must take all cost-increasing factors into account. As shown in $\mathbf{F i g . ~} \mathbf{1}$, this includes not only resources for the implementation of lectures and seminars, including the associated examination management (examinations, correction of term papers and Bachelor's theses), but also costs incurred for the theory-practice transfer. Precisely because the practical training is located in cooperative clinics, which are only to a limited extent overseen by the professorships of the universities, and is still provided by largely non-academic midwives, greater emphasis must be placed on the transfer of theory to practice. Moreover, the transfer of theory to practice is explicitly required by law [2]. The transfer of theory to practice includes: practical support, i.e. regular visits by teachers from the field of curricular teaching to the practice facilities; the linkage of theoretical and practical teaching content, e.g. in simulation training and OSCE examinations (OSCE = Objective-Structured Clinical Examination); and transfer seminars or problem-oriented learning whose aim is the continuous evaluation of the skills taught in the teaching-learning arrangements [5,7]. Based on the assumption that a total workload of 210 ECTS should be achieved within the framework of the study programme (whereby 1 ECTS is deposited with 30 hours each), this results (again using the example of the study programme in Tübingen) in a workload of approx. 50 semester periods per week (Semesterwochenstunden = SWS) per semester for 3 parallel cohorts with 30 students each for which personnel positions must be created. This does not take into ac- 


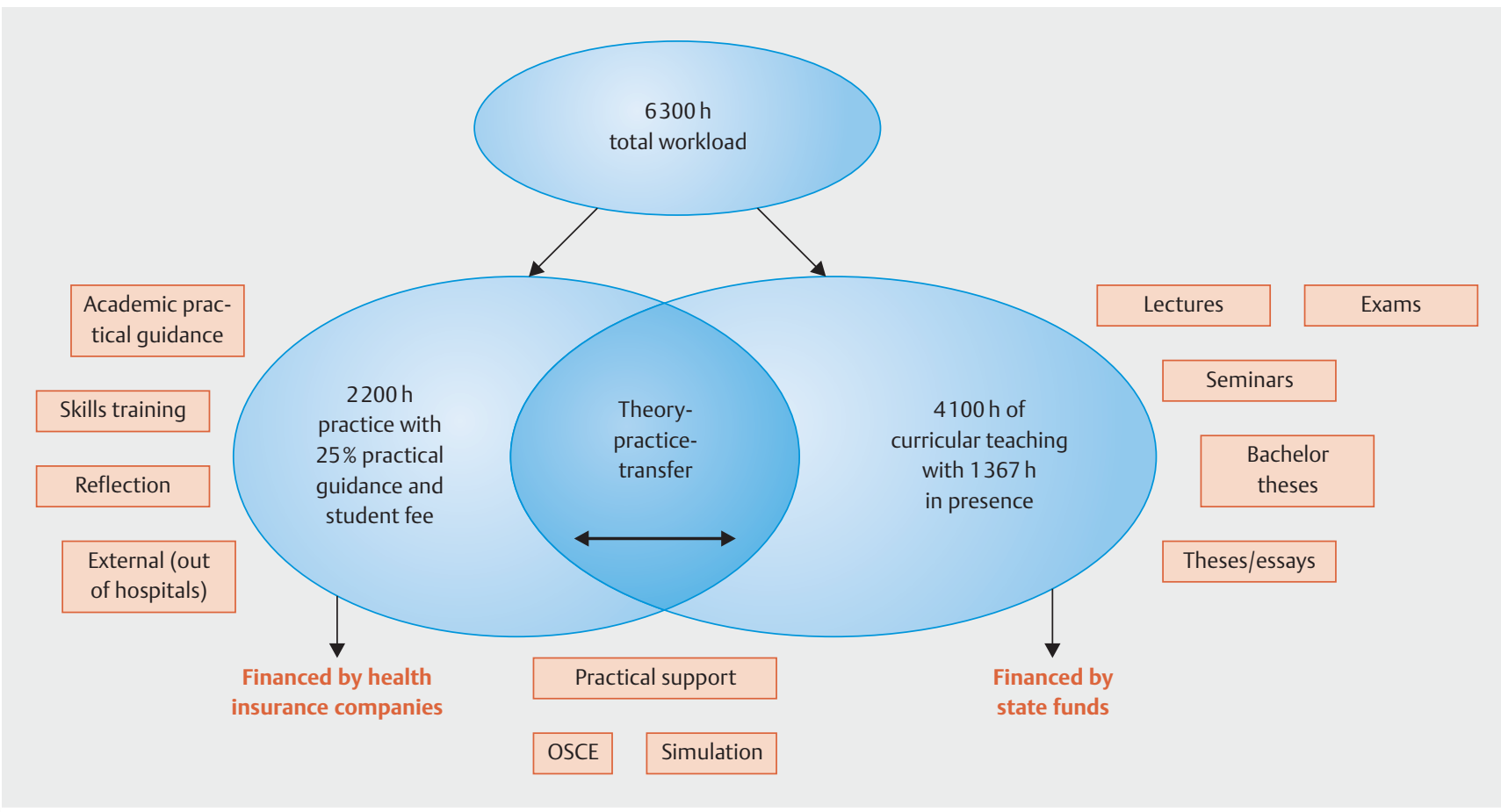

- Fig. 1 Rough structure and cost regime of a dual course in midwifery science.

count infrastructure costs; many universities are already considered underfinanced and overstaffed in terms of the available teaching and office rooms [8]. New courses of study cannot easily be integrated into the existing structures, especially since the HebG requires the implementation of simulation classrooms [2].

In addition, the assumption of costs for the $25 \%$ practical instruction by academically qualified midwives must be negotiated with the health insurance companies, as well as the costs for the practice remuneration of the students, which is to be paid at an "appropriate level" according to the HebG [2]. Initial estimates have shown that an additional 15,000 to 20,000 euros per year would have to be made available per place for the implementation of the practical instruction and the financing of the practice fee.

Further challenges of the HebG result from the defined admission criteria. For example, in the future all higher education institutions may offer midwifery study courses (i.e. both at universities or medical faculties with links to perinatal centres and teaching and research institutes and at universities of applied sciences or colleges without genuine links to hospital structures). A heterogenization of academic training (and thus also of the quality of training) is therefore to be expected [9], especially in view of the fact that the HebG wants to make it possible to take up a course of study even after completing secondary school leaving certificate and a subsequent 3-year nursing training [2], which does not correspond to the university self-perception. The law thus explicitly does not follow the demands of the German Science Council, which recommended that the training of midwives be located exclusively at medical faculties [10].

\section{Implications for Curricular Teaching}

The HebG and Midwifery Study and Examination Ordinance (Hebammenstudien- und Prüfungsverordnung - HebStPrV) stipulate that midwives are to be qualified in the future to provide evidence-based care for pregnant women, women in childbirth and women who have recently given birth. This legal premiss presupposes a university education on an evidence basis, both in terms of theoretical-curricular and practical teaching. By defining the competences to be acquired, the law offers vague indications of the structural location of study courses. It states, for example, that graduates should have "evidence-based knowledge and skills to promote physiological pregnancy, birth and puerperium”, but at the same time they should "recognise signs of irregularities that require medical treatment and cooperate with doctors and other professional groups in the planning, organisation, implementation, control and evaluation of care processes for women and their families with a pathological course during pregnancy, birth and the puerperium" [11]. In order to meet these requirements of interdisciplinary teamwork, students need to be sensitized to the necessity of interdisciplinary cooperation during their course of study [12]. This requires the simultaneous development of future-oriented teaching formats which also convey scientific and medical basics and are as interprofessional as possible, including students of other subjects of a medical faculty [3-5, 7, 9]. Interprofessional teaching formats are in the interest of all students, not only prospective midwives, and could also contribute to saving faculty resources by using synergy effects. Furthermore, the HebStPrV states that future midwives "should take into account and support the autonomy and self-determination of women, taking into account their rights, 
- Table 1 Areas of study and curricular location of the primary qualifying B. Sc. midwifery course in Tübingen.

\begin{tabular}{|c|c|c|c|}
\hline Midwifery in Theory and Practice & $\begin{array}{l}\text { Theoretical Medicine } \\
\text { and Natural Sciences }\end{array}$ & Health and Social Sciences & $\begin{array}{l}\text { Competence in Midwifery } \\
\text { Science }\end{array}$ \\
\hline $\begin{array}{l}\text { - Midwifery and nursing: self-conception } \\
\text { and principles } \\
\text { - Basic principles of midwifery practice } \\
\text { - Physiology of reproduction and } \\
\text { support of physiological birth } \\
\text { - Pregnancy support } \\
\text { - The newborn baby } \\
\text { - Care of women who have recently } \\
\text { given birth } \\
\text { - The midwife-led birth } \\
\text { - Operative care for pregnant women } \\
\text { and during childbirth } \\
\text { - Pathological pregnancies and births } \\
\text { - Monitoring, diagnosis and care } \\
\text { in an outpatient context } \\
\text { - Interventions in standardized and } \\
\text { complex situations }\end{array}$ & $\begin{array}{l}\text { - Fundamentals of physiology } \\
\text { and anatomy } \\
\text { - Microbiology, virology and } \\
\text { hygiene } \\
\text { - Natural scientific basics } \\
\text { - General medical compe- } \\
\text { tence, emergency medicine } \\
\text { - Obstetrical competence, } \\
\text { gynaecology and women's } \\
\text { health I and II }\end{array}$ & $\begin{array}{l}\text { - Social, conversation, } \\
\text { communication and } \\
\text { observation skills } \\
\text { - Elective subjects/ } \\
\text { elective range } \\
\text { - Psychosocial aspects, } \\
\text { bonding and women's } \\
\text { health } \\
\text { - Interprofessional action, } \\
\text { communication and } \\
\text { ethical evaluation within } \\
\text { the German health } \\
\text { system }\end{array}$ & $\begin{array}{l}\text { - Introduction to midwifery } \\
\text { science } \\
\text { - Health (care) system in } \\
\text { the context of midwifery } \\
\text { science and practice } \\
\text { - Health/midwifery scientific } \\
\text { thinking and methodical } \\
\text { competence } \\
\text { - I-III } \\
\text { - Prevention and health } \\
\text { promotion } \\
\text { - Evidence and clinical } \\
\text { decision making } \\
\text { - Applied midwifery science } \\
\text { (elective) } \\
\text { - Bachelor thesis and } \\
\text { presentation }\end{array}$ \\
\hline $\begin{array}{l}\text { Examination format: } \\
\text { Exams and OSCEs }\end{array}$ & $\begin{array}{l}\text { Examination format: } \\
\text { written exams/orals/term } \\
\text { papers }\end{array}$ & $\begin{array}{l}\text { Examination format: } \\
\text { written exams/orals/term } \\
\text { papers }\end{array}$ & $\begin{array}{l}\text { Examination format: } \\
\text { written exams/orals/term } \\
\text { papers }\end{array}$ \\
\hline $\begin{array}{l}\text { Characteristics: } \\
\text { - Longitudinal and competence- } \\
\text { oriented } \\
\text { - Teaching of theoretical and practical } \\
\text { skills with relevance to practical } \\
\text { activities (evidence-based) }\end{array}$ & $\begin{array}{l}\text { Characteristics: } \\
\text { - Longitudinal and } \\
\text { competence-oriented } \\
\text { - Interprofessional teaching } \\
\text { formats with other subjects } \\
\text { of the Medical Faculty (e.g. } \\
\text { human medicine, nursing) }\end{array}$ & $\begin{array}{l}\text { Characteristics: } \\
\text { - Longitudinal and } \\
\text { competence-oriented } \\
\text { - Interprofessional teach- } \\
\text { ing formats with other } \\
\text { university subjects (e.g. } \\
\text { sociology or philosophy) }\end{array}$ & $\begin{array}{l}\text { Characteristics: } \\
\text { - Longitudinal and } \\
\text { competence-oriented } \\
\text { - Development of a dedicated } \\
\text { research competence }\end{array}$ \\
\hline
\end{tabular}

their concrete life situation, ethnic origin, social, biographical, cultural and religious background, sexual orientation and transsexuality, intersexuality and the phase of life of women and their families" [11]. In addition, future midwives should "analyse scientifically founded legal, economic and social framework conditions, participate in social negotiation processes for quality-assured midwifery" and "analyse and reflect on scientifically founded professional ethical values and attitudes" [11]. The academic discipline of midwifery is thus implicitly defined as an interdisciplinary cross-sectional subject [13-15] which intersects with classical midwifery, medicine and the natural sciences, but also explicitly includes social and health science components (e.g. related to the evidence-based, target groupspecific development and implementation of prevention measures). Academically trained midwives should be qualified as health experts for the health of women of child-bearing age (going beyond the care of pregnant women, women who have recently given birth and women who are pregnant) and thus act as key players in a modular care structure to promote women's health [16].

In order to meet these requirements, competence-oriented modules in 16 areas of competence [7] that are considered relevant were assigned to four areas of study in the B. Sc. midwifery programme at the University of Tübingen ( $\bullet$ Table 1$)$. On the one hand, the area "midwifery in theory and practice" contains modules directly related to later practical work and develops corresponding competences in a longitudinal section based on evidence (2200 hours of practice required by law with academic practical support, skill training and simulation, each of which is linked to an accompanying lecture). On the other hand, there is the dimension "theoretical medicine and natural sciences", which includes courses in physiology, anatomy, microbiology, virology, hygiene, emergency medicine, internal medicine as well as gynaecology and obstetrics, and is designed to be interprofessional in order to partially facilitate joint learning by prospective midwives together with students of human medicine and nursing. The modules assigned to the study area "health and social sciences" are intended to enable students to provide psychosocial care for clients in the context of individual values, while the study area "competence in midwifery science" promotes the development of dedicated research expertise [17]. It is relevant that the individual areas of study not only enable students to acquire competence in a longitudinal section when viewed separately, but are also directly related to one another in terms of content, i.e. competencies in one area of study also promote in-depth acquisition of 


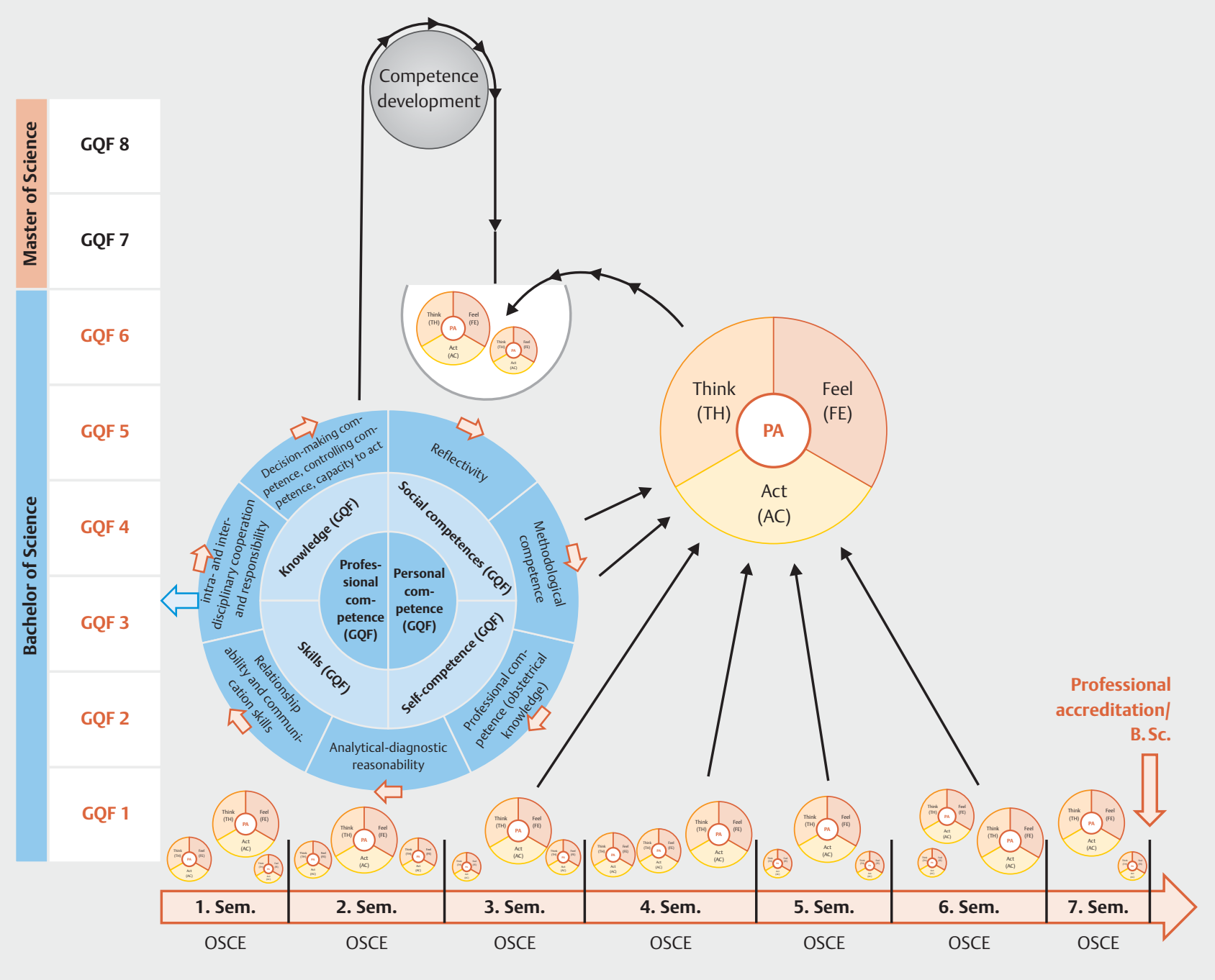

Fig. 2 Development of practical skills in the context of TH-FE-AC taxonomy in the bachelor's degree course in midwifery.

$\mathrm{GQF}=$ German Qualifications Framework; Sem. = semester; OSCE = Objective-Structured Clinical Examination; B. Sc. = Bachelor of Science.

competence in another area. Thus, a successively developed research competence is not only relevant in order to be able to understand scientific studies or (within the framework of the bachelor thesis) to carry out a research project under supervision, but also in order to develop evidence-based knowledge in the field of "midwifery in theory and practice" through in-depth reflection (e.g. related to activities of midwifery assisted birth, for which no evidence has been provided so far, e.g. vaginal seeding [18] or "hands-off" perineal protection [19]).

\section{Implications for Practical Teaching}

HebG and HebStPrV require evidence-based training in all relevant areas, which naturally includes modules with practical relevance $[2,11]$. Although not explicitly mentioned in the law, the academisation of the midwifery profession must locate all competencies at level 6 of the German Qualifications Framework (GQF), which is based on the European Qualifications Framework (EQF) and is in- tended to create comparability in the development of competencies throughout Europe $[20,21]$. Vocational training courses (including midwifery training, which has been carried out in Germany to date) are at GQF/EQF level 4, while a bachelor's degree course leads to GQF/EQF level 6 [7,20,21]. This presents a particular challenge in practice as the practical training of midwifery students will also include midwives without an academic degree for the time being [5, 7]. In order to enable the acquisition of competence at GQF/EQF level 6 in practice, a dedicated practical curriculum is required that defines and explains the successive acquisition of competence and evaluates the achievement of objectives. Within the framework of the development of the course of studies at the University of Tübingen, a model was developed in which the 7 key competencies of a midwife described in the literature (decision-making competence, controlling competence, capacity to act; reflectivity; methodological competence; professional competence (obstetrical knowledge); analytical-diagnostic reasoning ability; relational and communication skills; intra- and 
interdisciplinary cooperation and responsibility) [22-25] are assigned to the 4 competencies of the GQF schemes (social competences, self-competence, knowledge and skills in the dimensions of professional and personal competence) $[20,21]$.

Based on the assumption that all practical skills (always taught in close connection with the curricular components) contain all competencies to varying degrees, a taxonomy model was created for practical training which locates all practical activities (PA) (e.g. blood sampling) in the dimensions thinking (TH), feeling (FE) and acting (AC) $[5,7]$. As shown in $\mathbf{F i g . ~} \mathbf{2}$, it is assumed that competence development is comparable to a "steering control", which is "lifted up" by a weight. The weight to be carried represents the competence of a midwife, here understood as the 7 key competences that constantly interact with the $4 \mathrm{GQF}$ competences. The $x$-axis describes the development of the students' learning growth in the course of their studies while the $y$-axis shows the classification according to the German quality framework: the student's competence is promoted to higher levels in the course of their studies by gradually achieving learning outcomes during their studies and adding to the shell of the pull weight (competence development). However, the competence can only be raised if a sufficient pulling weight is able to change the competence level. This pull weight is formed by the individual learning outcomes (defined by the learning outcome taxonomy) of the practical content which is directly linked to curricular teaching. The numerous learning outcomes of the individual practical training parts flow into the collection pot of the pull weight and "move" the competencies along the y-axis to a higher level. It must be emphasised that the same practical topics with different learning outcomes accumulate over the course of the study in the shell of the train weight, which means that topics are learned repeatedly, but the content is built up. For example, the supervision of a woman in childbirth: theoretical and practical teaching and personal value development lead to an increase in learning. Identical practical contents of lower levels dissolve into identical practical contents from a higher level. A change in the level of competence can therefore only occur if enough different practical contents of higher level have been included in the train weight. The underlying model also rules out the possibility that learning in the teaching and learning process develops backwards - i.e. a lower competence level would be achieved as training progresses. An achieved level of learning outcomes in the individual practical training elements is always maintained. There can only be a standstill if no further gain in competence development is achieved. It is taken into account that competences are subject to a process of lifelong learning or require individual work experience for a comprehensive understanding, which is why the highest levels of the learning outcome taxonomy cannot yet be achieved in some practical activities within the framework of higher education [26].

At the end of each semester, an OSCE examination is held in the Tübingen programme to evaluate learning outcomes. The aim is to determine whether and to what extent the students have achieved the defined level of competence. At the same time, the OSCE exams serve as a quality assurance measure to check whether the content presented in the practical curriculum has been taught within the given framework. In view of the fact that, particularly in the case of larger student cohorts, a significant number of hospitals will be involved as dual partners in the implementation of practice-related study phases and that the practical training will also be provided by non-academic staff, the OSCE is of great importance as a control instrument in this context.

Initial attempts to conduct OSCE examinations among midwifery students were positive [27]; statistically significant high correlations between the examination results of individual examiners indicate a high validity of the midwives' OSCE [28]. The same stages of the examination were assessed by a doctor and a midwife with at least a bachelor's degree with no differences in grade points for the individual students (publication in preparation). OSCE examinations have long been regarded as the gold standard in human medicine training [29] and should also be taken into account in midwifery courses that are now being implemented. OSCE examination are valuable assessment tools for competence acquisition as midwifery students are confronted with practical training from the first semester onwards due to the dual structure of the course of study and the HebG now also designates the state examination, formerly known as "exam birth", as a simulated examination [2]. However, OSCE examinations are resource-intensive, which is why the necessary (personnel) capacities must be taken into account in the job calculations within the framework of the theory-practice transfer. In order to be able to realise the examination scenarios, both personnel (simulation patients, examiners) and material as well as suitable rooms (simulation delivery room) are necessary. Faculties of medicine can, if necessary, make use of existing structures for examination management of existing OSCE examinations in the study of human medicine and thus benefit from synergy effects, although the different specialist expertise must be taken into account.

\section{Digital Campus as a Vision of the Future}

The greatest challenge is that the described curricular and practical teaching formats must be developed within two years and this must take place in all federal states as the HebG no longer permits training formats involving midwifery schools from 2023 onwards [2]. Since the costs incurred have not been sufficiently taken into account to date and new courses of study will overburden the already limited rooms available at some universities (e.g. [30]), midwifery study courses could make use of the concept of a digital campus until sustainable financing concepts have been developed to expand the existing office and teaching space. Initial experience has been gained in this respect in the context of the COVID-19 pandemic which was linked in many states to the prohibition of face-to-face teaching at university level. In particular, synchronous teaching formats, in which lecturers and students interact directly with each other via webinars, were very positively received by students in Tübingen (publication in preparation); the evaluation of the learning outcomes is still pending. However, the implementation of digitally organised courses is only one component of a digital campus: the continuous supervision of students (e.g. digital consultation hours or the supervision of bachelor theses) can also be efficiently organised using digital formats. In order not to jeopardise the tight schedule of academization, the treading of new paths is required. This includes the creation of digitally organised study programmes which are then suc- 
cessively integrated into the presence teaching of the universities. Against this background, academic staff and professorships could initially also be partially housed in home offices for a transitional period yet to be defined, at least as far as teaching-related tasks, general activities within the framework of self-administration and research-related activities, such as data evaluation or the preparation of publications, are concerned. Web-based formats can also be used to hold team meetings, which is why scientists and teachers could spend a large part of their working time in their home office, at least for a transitional period, in order to allow universities to save resources during the transition period in view of the lack of rooms. It should also be noted, however, that although digital teaching formats can be used to supplement face-to-face teaching to ameliorate shortage of space in rapidly developing and expanding degree programmes, digital teaching cannot replace personal contact between teachers and students. The possibilities of a digital campus are also limited, especially when it comes to practice-oriented courses and examination formats (OSCE examinations). Although individual skills and transfer seminars can also be conducted via webinars, direct practical support must be integrated into the daily clinic routine.

The academization of midwifery science aims to redefine an academic discipline which is always associated with the implementation of a research landscape at universities and medical faculties. Research in the transition area between physiological and pathological course (related to pregnancy, birth and puerperium) has to take place locally, so it requires the implementation of a dedicated research infrastructure, docked onto the resources of the hospital and faculty. The development of a digital campus can relieve university resources so that lack of space does not endanger the necessary development of study courses. In the medium term, however, the states must provide funds not only for curricular teaching but also for the necessary infrastructure in order to promote the implementation of the new faculty in the university canon of subjects.

\section{Conclusions}

The legally-mandated full academization of midwifery is to be unreservedly welcomed. It ensures quality development of the profession in a time when obstetrics is becoming more complex. The time limits imposed on the implementation of academization, however, present a challenge for states and faculties.

Higher education institutions must develop innovative concepts for both curricular and practical teaching, fill professorships and negotiate the necessary resources with both the federal states and health insurance companies. In analogy to the study of human medicine, it is also necessary for different university locations to network with each other on a transnational level in the course of the curricular rough planning in order to be able to define minimum quality standards, especially for practical training. Here it is important to prevent existing formats from being used unreflectively in vocational training; rather, existing structures must be broken up, reconsidered, evaluated and adapted in line with the times. For this purpose, the introduction of a practical curriculum can be useful which not only addresses the successive acquisition of competencies but also provides opportunities to evaluate whether the course content has been taught in practice and has been understood by the students. The states are called upon to develop viable financing concepts not only to guarantee the necessary resources for the midwifery courses but also to counteract the underfunding that dominates in many places. Of course, parallel to the creation of new study courses, additional rooms must be provided on the basis of fully financed, sustainable solutions. One possibility would be to create some of the structures of a digital campus for midwifery courses. It is important not to isolate and decouple the newly developed courses of study from existing study courses. Because sustainable spatial concepts cannot be developed within the defined time horizon, a digital campus can relieve the burden on the resources of the universities for a transitional period. The academic training of midwives cannot be implemented "for free". University locations that are involved in corresponding courses of study require, over and above the mere financing of positions (professorships, research assistants, lecturers), a resource endowment that meets the entire requirements of this new qualification profile. Its anchoring in EU legislation underlines the need for appropriate recognition in health policy and support from the institutions providing funding. It is important to note that the nationwide creation of bachelor degree courses can only be understood as the first stage of the academisation process: the need for Master programmes with subsequent doctoral and post-doctoral opportunities is emerging in all states in the near future, in order to qualify midwives for management functions and to train qualified personnel and scientific leaders to continue the irreversible process of academisation. Here, concepts must be developed promptly to provide suitable locations with the necessary resources to develop and make available such advanced training courses.

\section{Conflict of Interest}

The authors declare that they have no conflict of interest.

References

[1] Europäisches Parlament. Richtlinie 2013/55/EU des Europäischen Parlaments und des Rates vom 20. November 2013 zur Änderung der Richtlinie 2005/36/EG über die Anerkennung von Berufsqualifikationen und der Verordnung (EU) Nr. 1024/2012 über die Verwaltungszusammenarbeit mit Hilfe des Binnenmarkt-Informationssystems („IMI-Verordnung“). Amtsblatt der Europäischen Union 2013; L353: 132-170. Online: https://www.kmk.org/fileadmin/pdf/ZAB/Richtlinien_der_EU/ Aenderung_RL_2005_36EG_2013_11_20_RL_2013_55EU.pdf; last access: 26.06 .2020

[2] Bundesgesetzblatt. Gesetz zur Reform der Hebammenausbildung und zur Änderung des Fünften Buches Sozialgesetzbuch (Hebammenreformgesetz - HebRefG). Bundesgesetzblatt 2019; (I/42): 1759-1777

[3] Plappert CF, Graf J, Schönhardt S et al. Wohin führt der Weg? Die Akademisierung des Hebammenberufs im Kontext der Reformierung des Hebammenausbildungsgesetzes. Frauenarzt 2019; 60: 691-694

[4] Plappert CF, Graf J, Simoes E et al. The Academization of Midwifery in the Context of the Amendment of the German Midwifery Law: Current Developments and Challenges. Geburtshilfe Frauenheilkd 2019; 79: 854862 
[5] Graf J, Plappert CF, Simoes E et al. Akademisierung des Hebammenberufs (Teil 2): Risiken - und wie sie in den Studiengängen bestmöglich vermieden werden können. Z Geburtsh Neonatol 2020; 224: 130-135

[6] Deutscher Bundestag. Gesetzentwurf der Fraktionen der CDU/CSU und SPD. Entwurf eines Gesetzes zur Reform der Hebammenausbildung und zur Änderung des Fünften Buches Sozialgesetzbuch (Hebammenreformgesetz - HebRefG). Drucksache 19/10612. Online: https://dip21. bundestag.de/dip21/btd/19/106/1910612.pdf; last access: 07.07.2020

[7] Schönhardt S, Plappert CF, Graf J et al. Neuordnung der Hebammenausbildung. Frauenheilkunde up2date 2020; 14: 211-223

[8] Lenhardt G. Hochschulen in Deutschland und in den USA. Deutsche Hochschulpolitik in der Isolation. Wiesbaden: VS Verlag für Sozialwissenschaften; 2005: 36

[9] Graf J, Zipfel S, Schönhardt S et al. The academization of midwifery: State-wide implementation of the new law governing the education of midwives (Hebammenreformgesetz) is leading to heterogeneous education. GMS J Med Educ 2020; 37: Doc37. doi:10.3205/zma001330

[10] Wissenschaftsrat. Empfehlungen zu hochschulischen Qualifikationen für das Gesundheitswesen. Berlin: Wissenschaftsrat; 2012. Online: https:// www.wissenschaftsrat.de/download/archiv/2411-12.pdf; last access: 01.07.2020

[11] Bundesgesetzblatt. Studien- und Prüfungsverordnung für Hebammen (HebStPrV). Bundesgesetzblatt 2020; (1/2): 39-62

[12] Simoes E, Graf J, Sokolov AN et al. Pregnancy-associated breast cancer: maternal breast cancer survival over 10 years and obstetrical outcome at a university centre of women's health. Arch Gynecol Obstet 2018; 298: 363-372

[13] De Vries R, Nieuwenhuijze M, van Crimpen R. The necessity and challenge of international midwifery science. International Journal of Childbirth 2011. doi:10.1891/2156-5287.1.1.61

[14] Renfrew MJ, McFadden A, Bastos MH et al. Midwifery and quality care: Findings from a new evidence-informed framework for maternal and newborn care. Lancet 2014; 384: 1129-1145

[15] Renfrew M. Midwifery matters. In: Murrary-Davis B, Hutton EK, Carty E, Kaufman K, Butler M, eds. Comprehensive Midwifery: The Role of the Midwife in Health Care Practice, Education, and Research. E-book. Online: https://ecampusontario.pressbooks.pub/cmroleofmidwifery/ chapter/midwifery-matters/; last access: 08.07.2020

[16] Wallwiener D, Simoes E, Brucker SY. Frauengesundheit als Perspektive der Frauenheilkunde. Gynäkologe 2016; 49: 643-648

[17] Eberhard Karls Universität Tübingen. Modulhandbuch des Studiengangs B.Sc. Hebammenwissenschaft. Tübingen: Eberhard Karls Universität Tübingen; 2020

[18] Lutz F, Gianom M. Vaginal Seeding - Chance oder Risiko? Hebamme 2018; 31: 45-53

[19] Aasheim V, Nilsen ABV, Reinar LM et al. Perineal techniques during the second stage of labour for reducing perineal trauma. Cochrane Database Syst Rev 2017; (6): CD006672. doi:10.1002/14651858.CD006672.pub3
[20] Europäisches Parlament; Europäischer Rat. Empfehlungen des Europäischen Parlamentes und des Rates vom 23. April 2008 zur Einrichtung des Europäischen Qualifikationsrahmens für lebenslanges Lernen. Amtsblatt der Europäischen Union 2008; C111/1-C111/7. Online: https:// eur-lex.europa.eu/legal-content/DE/TXT/PDF/?uri=CELEX:32008H0506 (01); last access: 08.07.2020

[21] Bundesministerium für Bildung und Forschung, Kultusminister Konferenz. Der Deutsche Qualifikationsrahmen für lebenslanges Lernen. Berlin 2020. Online: https://www.dqr.de/; last access: 08.07.2020

[22] Pehlke-Milde J. Ein Kompetenzprofil für die Hebammenausbildung: Grundlage einer lernergebnisorientierten Curriculumsentwicklung: 2009. Online: https://refubium.fu-berlin.de/bitstream/fub188/2171/1/ Diss_Pehlke-Milde_Kompetenzprofil_ohne_LL.pdf; last access: 01.07.2020

[23] Nicholls L, Webb C. What makes a good midwife? An integrative review of methodologically-diverse re-search. J Adv Nurs 2006; 56: 414-429

[24] Butler MM, Fraser DM, Murphy RJL. What are the essential competencies required of a midwife at the point of registration? Midwifery 2008; 24 : 260-269

[25] Skeide A. Witnessing as an embodied Practice in German Midwifery Care. In: Krause F, Boldt J, eds. Care in Healthcare: Reflections on Theory and Practice. Cham (CH): Palgrave Macmillan; 2018: 191-209

[26] Abteilung Hebammenwissenschaft Tübingen. Primärqualifizierender Studiengang Hebammenwissenschaft Tübingen (B.Sc.). Praxiscurriculum für die kompetenzbasierte, wissenschaftsorientierte und reflektierende Vermittlung praktischer Fertigkeiten. Tübingen 2020 (unveröffentlicht)

[27] Schönhardt S, Plappert C, Weinmann S, Graf J, Abele H. OSCE-Prüfungen zur Kompetenzüberprüfung von praktischen und kommunikativen Skills bei Hebammenstudierenden: Curriculare Einbettung und erste Erfahrungen in Tübingen. Gemeinsame Jahrestagung der Gesellschaft für Medizinische Ausbildung (GMA), des Arbeitskreises zur Weiterentwicklung der Lehre in der Zahnmedizin (AKWLZ) und der Chirurgischen Arbeitsgemeinschaft Lehre (CAL). Frankfurt am Main, 25.-28.09.2019. Düsseldorf: German Medical Science GMS Publishing House; 2019; DocP-0514. doi:10.3205/19gma298

[28] Chenot F, Ehrhardt M. Objective structured clinical examination (OSCE) in der medizinischen Ausbildung: Eine Alternative zur Klausur. Z Allg Med 2003; 79: 437-442

[29] Sloan DA, Donnelly MB, Schwartz RW et al. The objective structured clinical examination. The new gold standard for evaluating postgraduate clinical performance. Ann Surg 1995; 222: 735-742

[30] Ärzteblatt. Unimedizin Oldenburg: Neubau nicht im Etatentwurf berücksichtigt. Ärzteblatt 07.07.2020. Online: https://www.aerzteblatt. de/nachrichten/114484/Unimedizin-Oldenburg-Neubau-nicht-imEtatentwurf-beruecksichtigt; last access: 09.07.2020 